University of Massachusetts Amherst

ScholarWorks@UMass Amherst

Masters Theses

Dissertations and Theses

July 2016

\title{
Influence of Hierarchical Interfacial Assembly on Lipase Stability and Performance in Deep Eutectic Solvent
}

Stephanie M. Andler

University of Massachusetts Amherst

Follow this and additional works at: https://scholarworks.umass.edu/masters_theses_2

Part of the Food Biotechnology Commons, and the Food Processing Commons

\section{Recommended Citation}

Andler, Stephanie M., "Influence of Hierarchical Interfacial Assembly on Lipase Stability and Performance in Deep Eutectic Solvent" (2016). Masters Theses. 363.

https://doi.org/10.7275/8420515 https://scholarworks.umass.edu/masters_theses_2/363

This Open Access Thesis is brought to you for free and open access by the Dissertations and Theses at ScholarWorks@UMass Amherst. It has been accepted for inclusion in Masters Theses by an authorized administrator of ScholarWorks@UMass Amherst. For more information, please contact scholarworks@library.umass.edu. 


\section{INFLUENCE OF HIERARCHICAL INTERFACIAL ASSEMBLY ON LIPASE STABILITY AND PERFORMANCE IN DEEP EUTECTIC SOLVENT}

A Thesis Presented

by

STEPHANIE M. ANDLER

Submitted to the Graduate School of the University of Massachusetts Amherst in partial fulfillment of the requirements for the degree of

\section{MASTER OF SCIENCE}

May 2016

Food Science 


\section{INFLUENCE OF HIERARCHICAL INTERFACIAL ASSEMBLY ON LIPASE STABILITY AND PERFORMANCE IN DEEP EUTECTIC SOLVENT}

A Thesis Presented

by

STEPHANIE M. ANDLER

Approved as to style and content by:

Julie M. Goddard, Chair

Sam R. Nugen, Member

Vincent M. Rotello, Member

Eric A. Decker, Department Head Department of Food Science 


\section{ACKNOWLEDGEMENTS}

I would like to thank my advisor, Julie M. Goddard, for her support, enthusiasm, and guidance throughout my research. I would also like to extend a special thanks to my committee members, Sam R. Nugen, and Vincent M. Rotello for their input and time. Many thanks to Joey N. Talbert and Li-Sheng Wang for their assistance throughout this project. I would also like to acknowledge the BIOENG research group for their thoughtful insights and encouragement along the way. Finally, I would like to thank my family for their unwavering support.

This project was supported by the Agriculture and Food Research Initiative Grant no. 2014-67021-21584 from the USDA National Institute of Food and Agriculture, Nanotechnology for Agricultural and Food Systems (A1511). Additionally, this project

was funded, in part, by the Center for Hierarchical Manufacturing at The University of Massachusetts Amherst, an NSF Nanoscale Science \& Engineering Center supported by the National Science Foundation under NSF Grant No. CMMI-0531171. 


\begin{abstract}
INFLUENCE OF HIERARCHICAL INTERFACIAL ASSEMBLY ON LIPASE

STABILITY AND PERFORMANCE IN DEEP EUTECTIC SOLVENT
\end{abstract}

\author{
MAY 2016 \\ STEPHANIE M. ANDLER, B.S., UNIVERSITY OF ILLINOIS \\ M.S., UNIVERSITY OF MASSACHUSETTS AMHERST \\ Directed by: Professor Julie M. Goddard
}

Hierarchical systems that integrate nano- and macroscale structural elements can offer enhanced stability over traditional immobilization methods. Microparticles were synthesized using interfacial assembly of lipase with (CLMP-N) and without (CLMP) nanoparticles into a crosslinked polymeric core, to determine the impact of the highly ordered system on lipase stability in extreme environments. Kinetic analysis revealed the macrostructure significantly increases the turnover rate $\left(k_{\text {cat }}\right)$ following immobilization. The macrostructure also stabilized lipase at neutral and basic $\mathrm{pH}$ values, while the nanoparticles influenced stability under acidic $\mathrm{pH}$ conditions. A greener solvent, choline chloride and urea, was applied to produce sugar ester surfactants. Microparticles exhibited decreases in the turnover rate $\left(k_{\text {cat }}\right)$ and catalytic efficiency $\left(k_{\text {cat }} / K_{\mathrm{m}}\right)$ following exposure, but retained over $60 \%$ and $20 \%$ activity after exposure at $50{ }^{\circ} \mathrm{C}$ and $60{ }^{\circ} \mathrm{C}$, respectively. CLMP and CLMP-N outperformed the commercially available lipase per unit protein in the production of sugar esters. The utilization of greener solvent systems with hierarchical immobilized enzyme systems has the potential to improve processing efficiency and sustainability for the production of value-added agricultural products. Keywords: immobilization, ionic liquid, bioprocessing, nano, lipase, sugar ester 


\section{TABLE OF CONTENTS}

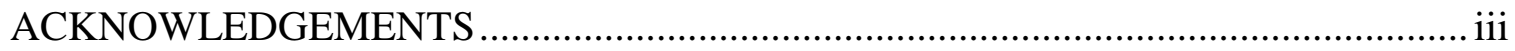

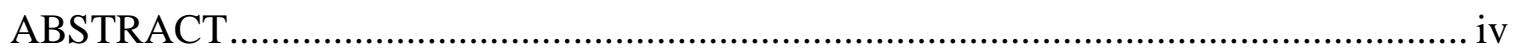

LIST OF TABLES ........................................................................................ vii

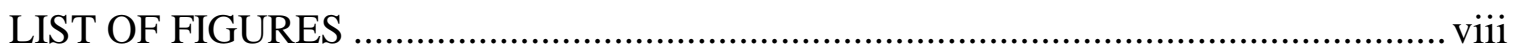

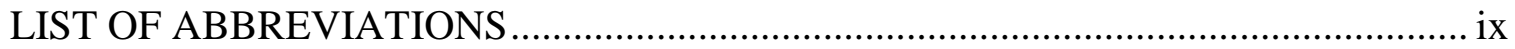

\section{CHAPTER}

1. INFLUENCE OF HIERARCHICAL INTERFACIAL ASSEMBLY ON LIPASE

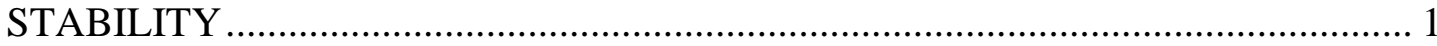

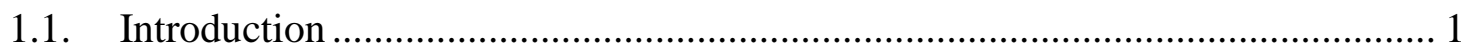

1.2. Materials and Methods ............................................................................ 4

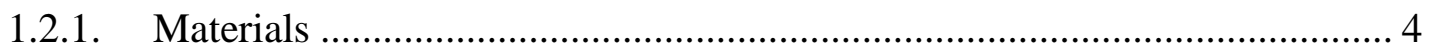

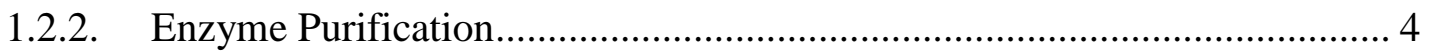

1.2.3. Fabrication of CLMP and CLMP-N ...................................................... 5

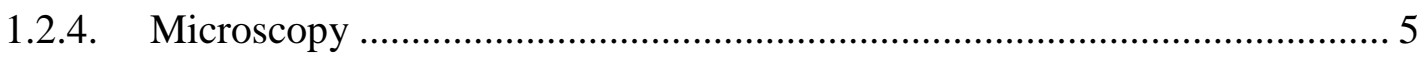

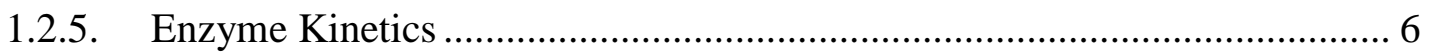

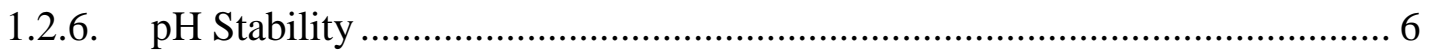

1.2.7. Stability in Deep Eutectic Solvents (DES) ........................................... 7

1.2.8. Influence of DES Exposure on Apparent Kinetic Parameters ..................... 7

1.2.9. Glucose Ester Synthesis in DES ….............................................. 8 
1.2.10. Statistical Analysis ........................................................................ 10

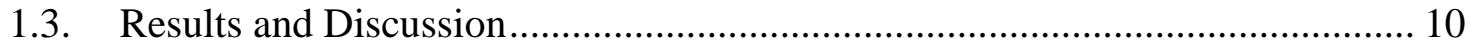

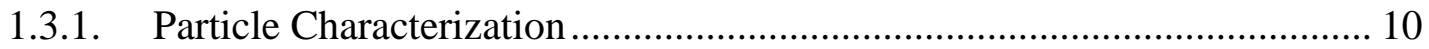

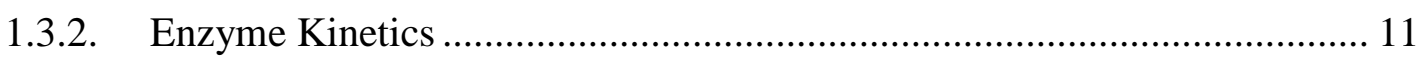

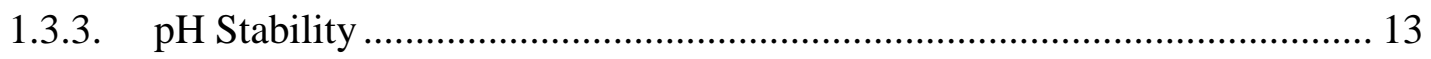

1.3.4. Stability in Deep Eutectic Solvent (DES) ......................................... 14

1.3.5. Influence of DES Exposure on Apparent Kinetic Parameters .................... 16

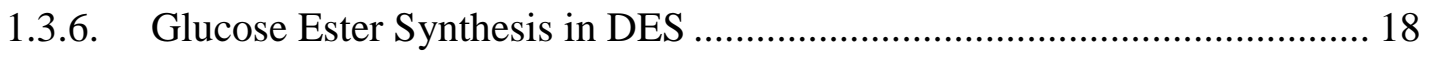

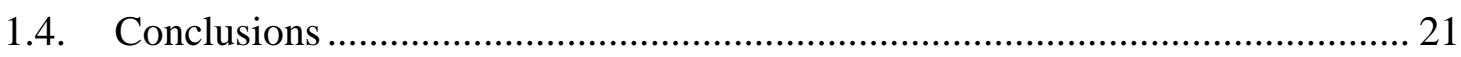

2. RECOMMENDATIONS FOR FUTURE RESEARCH.......................................... 23

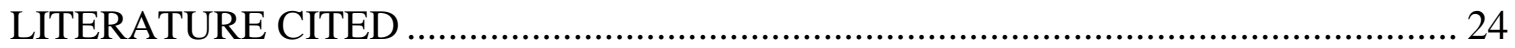




\section{LIST OF TABLES}

Table

Page

1. Apparent kinetic parameters of native lipase, CLMP-N, and CLMP. 12

2. Apparent kinetic parameters of CLMP-N and CLMP following exposure to 12 hours in $\mathrm{ChCl}: \mathrm{U}$ at $50^{\circ} \mathrm{C}$..

3. Apparent kinetic parameters of CLMP-N and CLMP following exposure to 12 hours in $\mathrm{ChCl}: \mathrm{U}$ at $60^{\circ} \mathrm{C}$. 


\section{LIST OF FIGURES}

Figure

Page

1. Schematic of hierarchical interfacial assembly of microparticles. ............................ 3

2. Proposed esterification reactions for glucose ester synthesis. ................................ 8

3. Scanning electron micrographs (bottom) and transmission electron micrographs (top) of CLMP (left) and CLMP-N (right)............................................................ 11

4. Apparent kinetics of CLMP-N, CLMP, and native lipase using resorufin butyrate as the

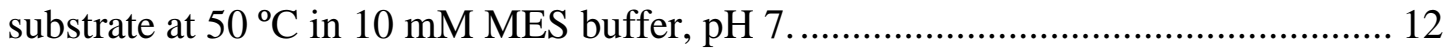

5. Relative activity retention of CLMP-N and CLMP after 24 hours exposure to $\mathrm{pH} 3,7$ and 10 buffers at $30{ }^{\circ} \mathrm{C}$

6. Relative activity retention of CLMP-N and CLMP after exposure to $\mathrm{ChCl}: \mathrm{U}$ at $50{ }^{\circ} \mathrm{C}$ and $60{ }^{\circ} \mathrm{C}$. Residual activity was testing using resorufin butyrate as the substrate at

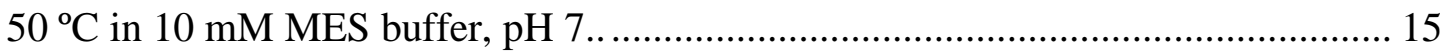

7. Percent conversion of glucose per $\mu \mathrm{g}$ protein in $\mathrm{ChCl}: \mathrm{U}$ at $50{ }^{\circ} \mathrm{C}$ after 12 hours exposure to Novozym 435, CLMP, and CLMP-N for a) direct esterification and b) transesterification. 19 


\section{LIST OF ABBREVIATIONS}

DES: Deep Eutectic Solvent

ChCl:U: Choline Chloride: Urea

CLMP: Cross-Linked Microparticle

CLMP-N: Cross-Liked Microparticle-Nanoparticles

N435: Novozym 435 


\section{CHAPTER 1}

\section{INFLUENCE OF HIERARCHICAL INTERFACIAL ASSEMBLY ON LIPASE STABILITY}

\subsection{Introduction}

Lipases in bioprocessing can catalyze the production of value-added agricultural products such as food-grade emulsifiers (e.g. sugar esters) that can be produced from agricultural waste streams. ${ }^{1-3}$ Traditionally, organic solvents have been used for these biotransformations. ${ }^{4-11}$ To alleviate health and environmental concerns associated with organic solvents, researchers point to the use of so-called 'greener solvents' which have low volatility, low toxicity, and high biodegradability. ${ }^{12}$ Deep eutectic solvents are advantageous to organic solvents for lipase mediated biotransformations, as a result of their ability to solubilize both polar and nonpolar esterification reactants. ${ }^{2,13-19}$ Mixtures of choline chloride and urea $(\mathrm{ChCl}: \mathrm{U})$ form a low-cost deep eutectic solvent with a combined freezing point of $12^{\circ} \mathrm{C} .{ }^{14}$ The inherent high viscosity of $\mathrm{ChCl}: \mathrm{U}$ hinders the industrial implementation in enzymatic processes; however, viscosity can be decreased by increasing reaction temperature, ${ }^{14}$ which in turn can denature enzymes. Researchers have explored enzyme immobilization techniques (e.g. physical adsorption, entrapment, crosslinking, and covalent attachment) to improve enzyme stability. ${ }^{20,21}$ However, challenges remain with traditional immobilization methods including loss of activity, restriction of active site accessibility, and loss of protein from the surface.

Nanomaterials (e.g. nanoparticles, nanofibers, nanorods, nanoporous silica) are Candidates for enzyme stabilization due to their high surface area, resulting in increased protein loading, as well as their enhancement of enzyme activity and stability. ${ }^{22-24}$ 
Nanoparticles can impact the microenvironment of enzymes by decreasing both lateral protein-protein interactions, as well as protein interactions with the surface, resulting in increased enzyme activity. ${ }^{25-28}$ Additionally, nanomaterial surface chemistry can be altered using capping agents, such as dopamine, to increase the affinity for enzyme immobilization. ${ }^{29,30}$ A main drawback of nanoimmobilization is the ability to efficiently recover and recycle the enzyme, even when magnetic properties are imparted to nanomaterials. ${ }^{28,31}$ Specifically, recovery from viscous solvents, such as deep eutectic solvents, could be challenging to achieve. Larger structures can facilitate recovery of the enzyme through standard methods (e.g. centrifugation), however the immobilized enzymes need to retain activity after repeated use. ${ }^{32}$ Commercially available lipase is adsorbed on acrylic resin beads (Novozym 435), permitting recovery, but is also susceptible to protein leaching. ${ }^{33}$ Therefore, immobilization techniques incorporating both macroscale and nanoscale features, may improve the commercial feasibility of immobilized enzyme systems.

We have previously reported a hierarchical assembly technique for enzyme immobilization in which lipase-nanoparticle conjugates interfacially assemble around a macroscale polymeric core resulting in cross-linked microparticles (CLMPs) (Figure 1). ${ }^{33,34}$ This technique harnessed the magnetic and interfacial properties of the nanoparticles and the facile recovery of the macroscale core. ${ }^{33,35,36}$ These hierarchically assembled microparticles exhibited stability against protein leaching, and displayed enhanced stability to $\mathrm{pH}$ and temperature extremes, compared to both native lipase and Novozym $435 .^{33}$ There remains a need to demonstrate the performance of these hierarchical structures under commercially relevant conditions; specifically, limited 
research exists on the use of deep eutectic solvents for the production of sugar esters. ${ }^{15,37}$ Further, understanding how nanoparticles and core material influence enzyme stability can help develop industrially feasible immobilized enzyme systems.

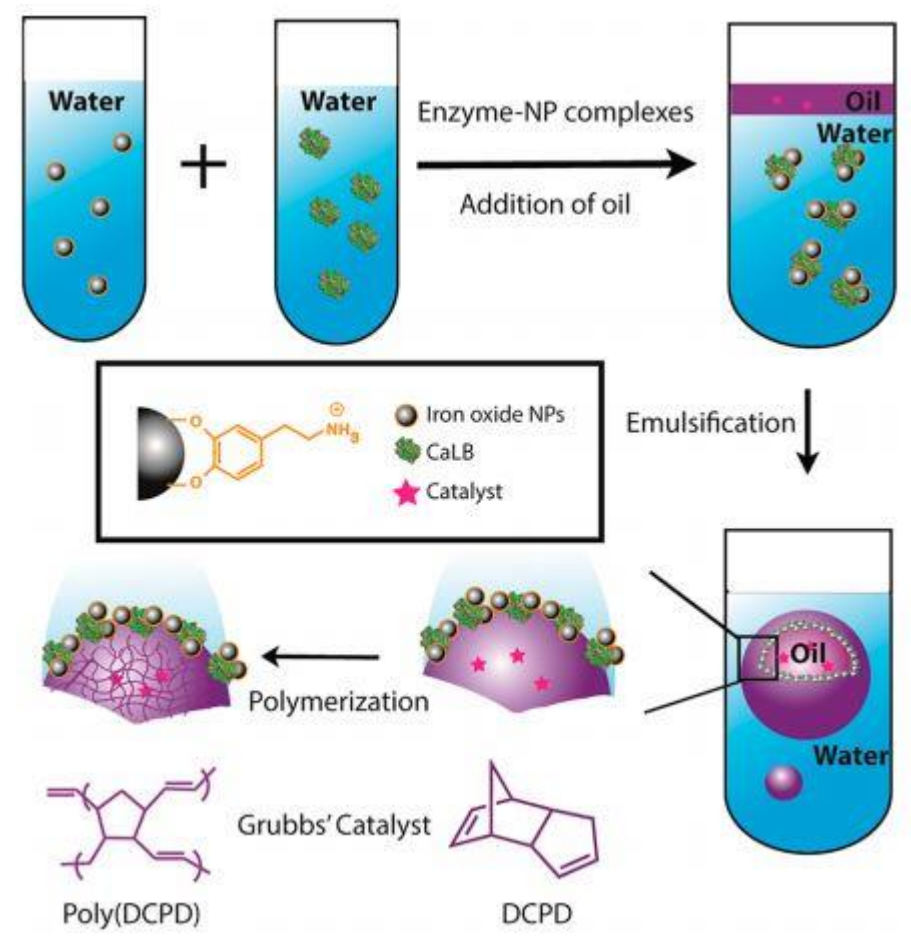

Figure 1. Schematic of hierarchical interfacial assembly of microparticles. Reprinted with permission from J.N. Talbert, L.-S. Wang, B. Duncan, Y. Jeong, S.M. Andler, V.M. Rotello, et al., Immobilization and Stabilization of Lipase (CaLB) through Hierarchical Interfacial Assembly, Biomacromolecules. $15 \quad$ (2014) 3915-3922. doi:10.1021/bm500970b. Copyright 2016. American Chemical Society.

The aim of this research was to characterize the performance of hierarchically assembled lipase nanocomposites in deep eutectic solvents as well as their efficacy in producing sugar ester surfactants. Synthesis of lipase CLMPs with and without nanoparticles enabled quantitative determination of the influence of nanostructures and macrostructures on the stability of lipase in denaturing conditions, including greener solvents. Hierarchically ordered composites were prepared as described previously, ${ }^{33}$ with slight modification to create microparticles in the absence of nanoparticles, to 
analyze kinetic parameters $\mathrm{pH}$ stability, and performance in $\mathrm{ChCl}: \mathrm{U}$. This series of experiments aimed to determine the extent to which the nanoparticles and core material stabilized the microenvironment and overall stability of lipase in a commercially relevant application.

\subsection{Materials and Methods}

\subsubsection{Materials}

Lipase CV-CALBY (Candida antarctica lipase B) was purchased from Chiralvision (Leiden, Netherlands). Resorufin butyrate was purchased from Santa Cruz Biotechnology, Inc. (Dallas, TX, USA). Vinyl laurate was purchased from MP Biomedicals (Santa Ana, CA, USA). Diethylene glycol, sodium hydroxide, iron (III) chloride hexahydrate, hydroxytyramine hydrochloride (dopamine), choline chloride, glycerol, sand (40-100 mesh), and syringe filters $(0.22 \mu \mathrm{m})$ were purchased from Fisher Scientific (Fairlawn, NJ, U.S.A.). Iron(II) chloride tetrahydrate, dicyclopentadiene, ruthenium-based 1st generation Grubbs' catalyst, trichlorobenzene, urea, lauric acid, glucose, $4 \AA$ molecular sieves, Amicon Ultra $0.5 \mathrm{ml}$ centrifugal filter devices (10K MWCO), and lipase acrylic resin from Candida antarctica (Novozym 435) were purchased from MilliporeSigma (Darmstadt, Germany).

\subsubsection{Enzyme Purification}

A $10 \%$ solution of lipase (wt/vol) in MES buffer was passed through a $0.22 \mu \mathrm{m}$ syringe filter attached to a luer-lock syringe, then distributed into $0.5 \mathrm{~mL} 10 \mathrm{~K}$ MWCO microcentrifuge tubes. The tubes were centrifuged for $14,000 \times \mathrm{g}$ for 15 minutes, followed by retentate dilution to approximately $1 \mathrm{mg}$ protein $/ \mathrm{ml}$. Protein content was initially determined using the bicinchoninic acid (BCA) assay, read using a wavelength 
of $562 \mathrm{~nm}$ against a standard curve of bovine serum albumin. ${ }^{38}$ A standard curve of lipase was then constructed at $280 \mathrm{~nm}$ and used for regular analysis of purified lipase. Lipase was diluted in $10 \mathrm{mM}$ MES buffer, $\mathrm{pH} 7$, to $111 \mu \mathrm{g}$ protein/ml and stored in the refrigerator until further use.

\subsubsection{Fabrication of CLMP and CLMP-N}

CLMP-N and CLMP were fabricated as described previously, with minor modification for CLMP fabrication (Figure 1). ${ }^{33,34}$ Dopamine capped iron oxide nanoparticles were prepared via a one-pot procedure as described previously. ${ }^{30,33,34}$ The aqueous phase of both CLMP-N and CLMP consisted of $55.5 \mu \mathrm{g} / \mathrm{mL}$ purified lipase, with the addition of $100 \mu \mathrm{g} / \mathrm{mL}$ dopamine-capped iron oxide nanoparticles for CLMP-N, which associated with the enzyme for 5 minutes prior to amalgamation. The oil phase, containing 0.42 M toluene, $6 \mathrm{mM}$ Grubb's Catalyst, $6.67 \mathrm{M}$ dicyclopentadiene, and 0.4 $\mathrm{M}$ trichlorobenzene, was added $10 \%$ ( $\mathrm{vol} / \mathrm{vol})$ to the aqueous phase $(90 \% \mathrm{vol} / \mathrm{vol})$ and emulsified for 30 seconds (4200 cpm, Wykle Research). After incubation at room temperature (ca. $22^{\circ} \mathrm{C}$ ) for 5 hours, CLMP-N and CLMP were centrifuged $(2000 \mathrm{x} \mathrm{g}, 30$ seconds, $3.8 \mathrm{~cm}$ tube height), washed three times with nanopure water, and stored in 10 mM MES buffer, $\mathrm{pH} 7$, at $4{ }^{\circ} \mathrm{C}$ for further testing.

\subsubsection{Microscopy}

Scanning electron micrographs were obtained by the Rotello Group, using a FEI Magellan 400 Field-Emission Scanning Electron Microscope with a $1.0 \mathrm{kV}$ acceleration voltage. Transmission electron micrographs were obtained using a JEOL 2000-FX 200 $\mathrm{kV}$ on $\mathrm{CF}-400-\mathrm{Cu}$ carbon film square mesh copper grid (Electron Microscopy Science; 
Hatfield, PA). Micrographs are representative of five images acquired at random locations from each of two independent samples.

\subsubsection{Enzyme Kinetics}

CLMP, CLMP-N, and purified native enzyme kinetics were analyzed according to previous work with slight modification. ${ }^{33,34}$ Briefly, all samples were tested at a final protein concentration of approximately $1.67 \mu \mathrm{g} / \mathrm{mL}$, with resorufin butyrate substrate concentrations ranging from 1-200 $\mu \mathrm{M}$ in $10 \mathrm{mM}$ MES buffer, $\mathrm{pH}$ 7. Sample reading was performed at $50{ }^{\circ} \mathrm{C}$ under constant (medium) shaking, and fluorescence values were read every 30 seconds for 12 minutes at 528/20 nm excitation and 590/20 nm emission wavelengths (Biotek Synergy). Rates were determined from an empirically calculated extinction coefficient derived from a standard curve of resorufin sodium salt. MichaelisMenten enzyme kinetics were used to extrapolate the Michaelis constant $\left(K_{\mathrm{m}}\right)$ and maximum velocity $\left(\mathrm{V}_{\max }\right)$ from a linear regression plot of substrate concentration versus velocity (v. 5.04, Graphpad Software, Inc., La Jolla, CA, U.S.A.). Assuming a molecular weight of $33,000 \mathrm{Da}$ for CaLB, the turnover number $\left(k_{\mathrm{cat}}\right)$ was calculated by dividing $\mathrm{V}_{\max }$ by the enzyme concentration.

\subsection{6. pH Stability}

CLMP, CLMP-N, and purified native lipase were diluted in $10 \mathrm{mM}$ buffers adjusted to $\mathrm{pH} 3,7$, and 10 (sodium citrate, sodium phosphate, sodium carbonate buffers, respectively) buffers to an estimated protein concentration of $15 \mu \mathrm{g} / \mathrm{mL}$. Samples were incubated at $30^{\circ} \mathrm{C}$ under constant rotation for 24 hours then diluted to approximately 1.67 $\mu \mathrm{g} / \mathrm{mL}$ protein in $0.1 \mathrm{M}$ MES buffer, $\mathrm{pH}$ 7. Activity measurements were performed using the synthetic substrate resorufin butyrate $(10 \mu \mathrm{M}$ in $10 \mathrm{mM}$ MES buffer, $\mathrm{pH} 7) .^{33}$ 
Fluorescence values were obtained every 30 seconds for 12 minutes, and subsequent rates were determined as described previously. Activity retention was calculated in relation to the original CLMP/CLMP-N/Native activities that were not exposed to $\mathrm{pH}$ changes.

\subsubsection{Stability in Deep Eutectic Solvents (DES)}

CLMP and CLMP-N were dispersed in ChCl:U at a protein concentration of approximately $15 \mu \mathrm{g} / \mathrm{mL}$. Samples were tested at 2, 4, 6, 12, 24, 36, and 48 hours at either $50{ }^{\circ} \mathrm{C}$ or $60{ }^{\circ} \mathrm{C}$, and washed with nanopure water before centrifugal recovery (2000 $\mathrm{x}$ g, 2 minutes, $3.8 \mathrm{~cm}$ tube height). Final dilution to $0.167 \mu \mathrm{g} / \mathrm{mL}$ in $10 \mathrm{mM}$ MES buffer pH 7 ensured negligible interactions of residual DES with resorufin butyrate. Activity measurements were conducted and analyzed as described previously. Activity retained was calculated as relative to the original CLMP/CLMP-N that was not exposed to elevated temperatures and DES.

For modeling, nonlinear regression, accounting for immobilized enzyme systems, was used based on a series-type deactivation model (Equation 1 and Equation 2). ${ }^{33,39,40}$ $E q 1: E \stackrel{k_{1}}{\rightarrow} E_{I} \stackrel{k_{2}}{\rightarrow} E_{D}$

Eq 2: activity $=\alpha_{2}+\left[1+\frac{\alpha_{1} k_{1}}{k_{2}-k_{1}}-\frac{\alpha_{2} k_{2}}{k_{2}-k_{1}}\right] \exp \left(-k_{1} t\right)-\left[\frac{\alpha_{1} k_{1}}{k_{2}-k_{1}}-\frac{\alpha_{2} k_{1}}{k_{2}-k_{1}}\right] \exp \left(-k_{2} t\right)$

Where: $\mathrm{t}=$ time, $\mathrm{E}=$ native enzyme specific activity, $\mathrm{E}_{\mathrm{I}}=$ enzyme intermediate specific activity, $\mathrm{E}_{\mathrm{D}}=$ denatured enzyme activity, $\alpha_{1}=\mathrm{E}_{\mathrm{I}} / \mathrm{E}$ relative specific activity, $\alpha_{2}=$ $\mathrm{E}_{\mathrm{D}} / \mathrm{E}$ relative specific activity, $\mathrm{k}_{1}=\mathrm{E} \rightarrow \mathrm{E}_{\mathrm{I}}$ rate constant, and $\mathrm{k}_{2}=\mathrm{E}_{\mathrm{I}} \rightarrow \mathrm{E}_{\mathrm{D}}$ rate constant.

\subsubsection{Influence of DES Exposure on Apparent Kinetic Parameters}

CLMP and CLMP-N were dispersed in $\mathrm{ChCl}: \mathrm{U}$, at an estimated protein concentration of $15 \mu \mathrm{g}$ protein $/ \mathrm{mL}$, and incubated at $50{ }^{\circ} \mathrm{C}$ or $60^{\circ} \mathrm{C}$. After 12 hours, 
samples were washed with nanopure water and recovered through centrifugation $(2000 \mathrm{x}$ $\mathrm{g}, 2$ minutes, $3.8 \mathrm{~cm}$ tube height). Samples were diluted with $10 \mathrm{mM}$ MES buffer, $\mathrm{pH} 7$ and tested for kinetics using resorufin butyrate as a substrate, as described previously, with minor modifications. Substrate concentrations tested ranged from 5-100 $\mu \mathrm{M}$ to facilitate sample handling. Unexposed CLMP and CLMP-N were tested for apparent kinetic parameters simultaneously for comparison.

\subsubsection{Glucose Ester Synthesis in DES}

Lipase can participate in two esterification reactions used to produce sugar esters: direct esterification and transesterification (Figure 2). The byproducts from direct esterification and transesterification are water and ethenol (which likely tautomerizes to acetaldehyde), respectively. ${ }^{16}$ Lipase is more active towards the transesterification reaction; however, the water byproduct of direct esterification is more desirable for greener processing.

Direct Esterification

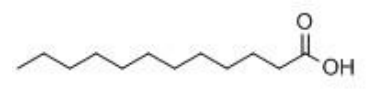

Lauric Acid

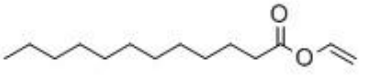

Vinyl Laurate

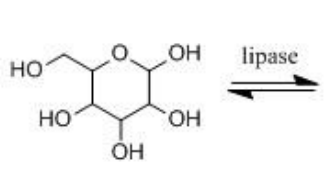

Glucose

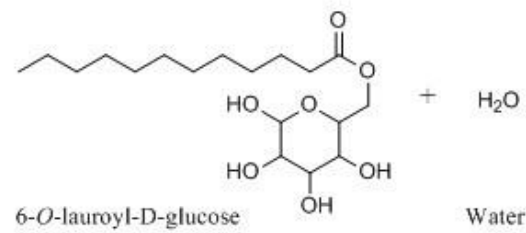

Transesterification

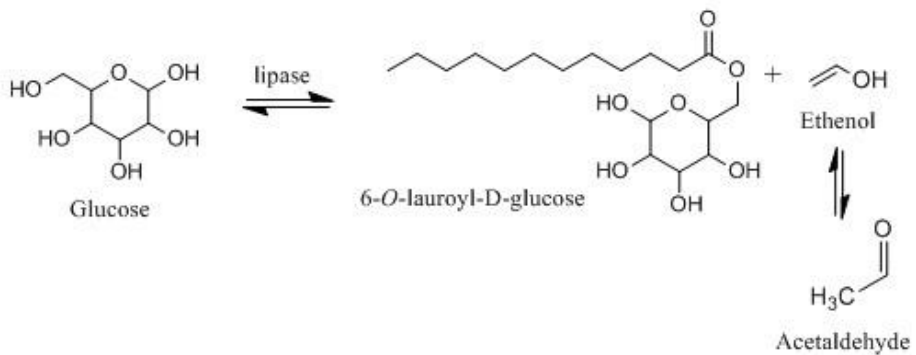

Figure 2. Proposed esterification reactions for glucose ester synthesis. 
For direct esterification, $\mathrm{ChCl}: \mathrm{U}$ was dried over molecular sieves for 48 hours prior to dissolution of reactants. Glucose and lauric acid (1:1 molar ratio, $222 \mathrm{mM})$ were suspended in $\mathrm{ChCl}: \mathrm{U}$, as described previously, with the addition molecular sieves, ${ }^{41}$ and rotated at $50{ }^{\circ} \mathrm{C}$ for 12 hours. The reaction began by adding $50 \mathrm{mg}$ Novozym 435 to 0.5 $\mathrm{mL}$ of the reaction solution, with approximately $150 \mathrm{mg}$ molecular sieves. For CLMP/CLMP-N, $1 \mathrm{~mL}$ of microparticles was centrifuged for 30 seconds $(2,000 \mathrm{x} \mathrm{g}, 3.8$ $\mathrm{cm}$ tube height) and the buffer was removed. To start the reaction, $0.5 \mathrm{~mL}$ of the reaction solution was added to the collected CLMPs (estimated $50 \mu \mathrm{g}$ protein/tube), along with approximately $150 \mathrm{mg}$ molecular sieves. After samples reacted under rotation for 12 hours at $50{ }^{\circ} \mathrm{C}, 0.5 \mathrm{~mL}$ of deionized water was added to each sample and centrifuged for 2 minutes $(2,000 \mathrm{x} \mathrm{g}, 3.8 \mathrm{~cm}$ tube height). To determine residual glucose, $0.5 \mathrm{~mL}$ of the aqueous phase was reacted with $0.5 \mathrm{~mL}$ DNS reagent and incubated for 5 minutes in a hot water bath $\left(100{ }^{\circ} \mathrm{C}\right){ }^{42}$ Samples were diluted, cooled on ice for 3 minutes, and read spectrophotometrically at $540 \mathrm{~nm}$. Sample absorbances were compared to a standard curve of glucose, originating from the initial reaction solution and exposed to identical dilution and centrifugation. Percent conversion was determined by the loss of glucose in solution, then normalized to the amount of protein present.

For transesterification, $222 \mathrm{mM}$ glucose and $222 \mathrm{mM}$ vinyl laurate were suspended in $\mathrm{ChCl}: \mathrm{U}$ and rotated at $50{ }^{\circ} \mathrm{C}$ for 12 hours prior to reaction with lipase. To prepare CLMP/CLMP-N samples, $1 \mathrm{~mL}$ of microparticles was centrifuged for 30 seconds $(2,000 \mathrm{x} \mathrm{g}, 3.8 \mathrm{~cm}$ tube height). The storage buffer was removed and $0.5 \mathrm{~mL}$ of the reaction solution was added to CLMP/CLMP-N, as well as to $50 \mathrm{mg}$ Novozym 435 to 
start the reaction. After 12 hours rotation at $50{ }^{\circ} \mathrm{C}$, samples were analyzed for glucose content and percent conversion, as described previously.

\subsubsection{Statistical Analysis}

Unless otherwise reported, analyses were performed in quadruplicate and results are representative of experiments repeated on two independent days. Statistical analysis was performed using Graphpad Prisim software (v. 5.04, Graphpad Software, La Jolla, CA). Curve fitting analysis, unpaired t-test, and one-way analysis of variance (ANOVA) with Tukey's multiple comparison test identified statistical differences among samples at $\mathrm{p}<0.05$.

\subsection{Results and Discussion}

\subsubsection{Particle Characterization}

SEM and TEM micrographs revealed a rough microparticle surface for CLMP-N, (Figure 3). These clusters at the surface are hypothesized to be the electrostatically coupled lipase and iron oxide nanoparticles. CLMP showed a smoother microparticle surface, likely because of the absence of iron oxide nanoparticles. The large size of the particles (average $10 \mu \mathrm{M}$ ), facilitates rapid separation of the particles through simple centrifugation, as opposed to nanomaterials, which can take hours to magnetically separate. $^{33,43}$ 

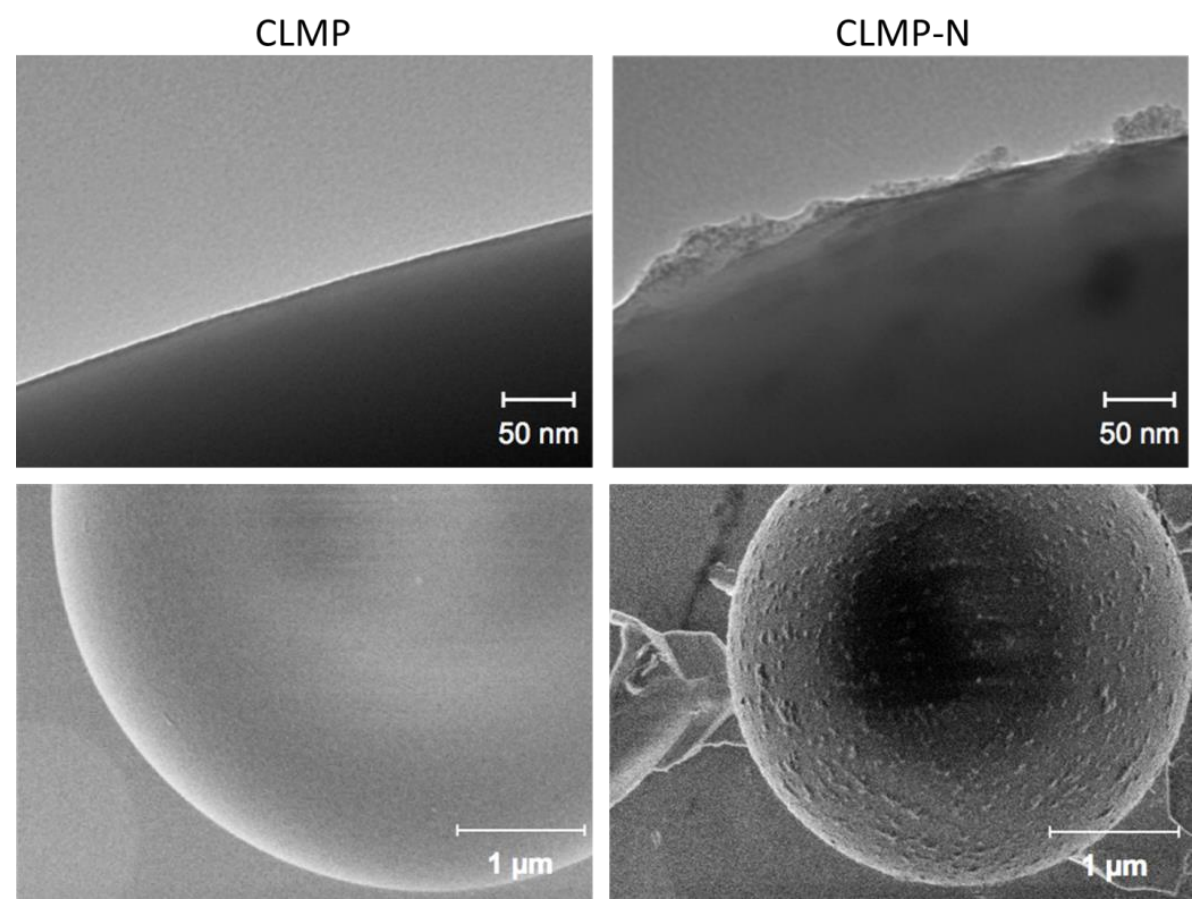

Figure 3. Scanning electron micrographs (bottom) and transmission electron micrographs (top) of CLMP (left) and CLMP-N (right). Micrographs are representative of five images acquired at random locations from each of two independent samples. Images courtesy Li-Sheng Wang.

\subsubsection{Enzyme Kinetics}

Michaelis constant $\left(K_{\mathrm{m}}\right)$, turnover number $\left(k_{\mathrm{cat}}\right)$, and catalytic efficiency $\left(k_{\mathrm{cat}} / K_{\mathrm{m}}\right)$ were characterized for native lipase, CLMP-N, and CLMP to quantify the influence of the hierarchical assembly technique on enzyme kinetics (Figure 4). Upon immobilization of native lipase into CLMP, $K_{\mathrm{m}}$ increases form $13.84 \mu \mathrm{M}$ to $23.68 \mu \mathrm{M}$ (Table 1 ). Compared to CLMP, the presence of nanoparticles in CLMP-N results in a decrease in the apparent $K_{\mathrm{m}}$ to $21.06 \mu \mathrm{M}$. These data suggest the cross-linked core imparts some mass transfer restrictions to the immobilized lipase. 


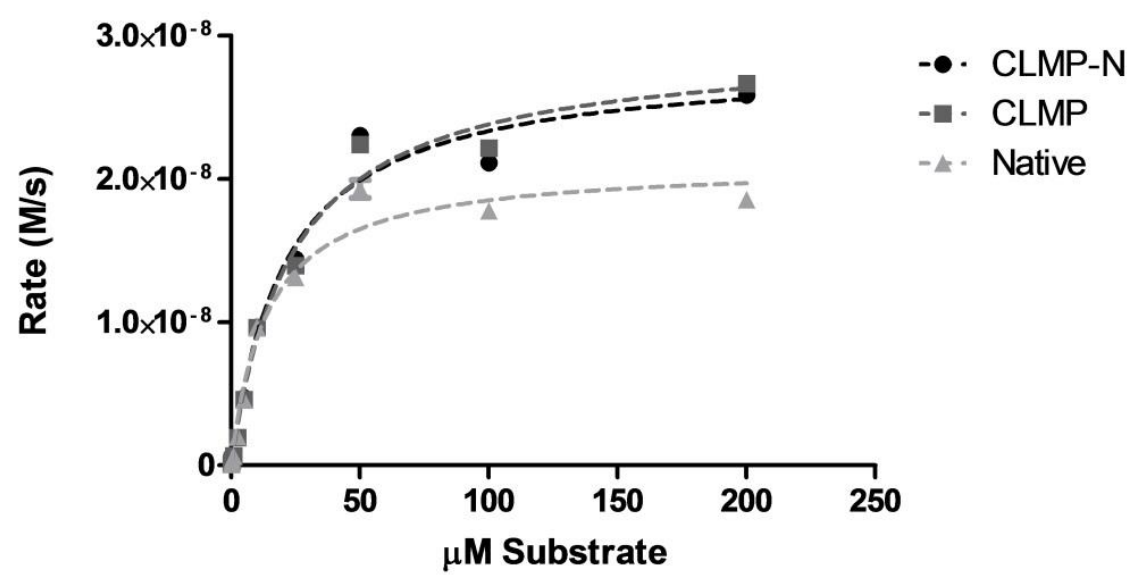

Figure 4. Apparent kinetics of CLMP-N, CLMP, and native lipase using resorufin butyrate as the substrate at $50{ }^{\circ} \mathrm{C}$ in $10 \mathrm{mM}$ MES buffer, $\mathrm{pH}$ 7. Values represent average \pm standard deviation of $n=4$ determinations. Data are representative of experiments performed on two independent days.

CLMP-N and CLMP displayed a $k_{\text {cat }}$ value of $0.56 \mathrm{sec}^{-1}$, and $0.58 \mathrm{sec}^{-1}$, demonstrating an increased $\mathrm{V}_{\max }$ upon immobilization. Both of these values are higher than the native lipase $k_{\mathrm{cat}}$ of $0.42 \mathrm{sec}^{-1}$, and are in agreement with previously reported literature. ${ }^{33}$ Kinetic trends were similar between days, but absolute values differed, such that significant differences may not exist when the microparticles are applied in industrial bioprocessing applications. The general increase in apparent turnover rate supports that immobilized lipase outperforms native lipase when situated at a hydrophobic interface. ${ }^{44}$

Table 1. Apparent kinetic parameters of native lipase, CLMP-N, and CLMP. Values represent $95 \%$ confidence intervals of $n=4$ determinations with superscripts indicating significant differences at $p<0.05$. Data are representative of experiments performed on two independent days.

\begin{tabular}{|c|c|c|c|}
\hline & $\begin{array}{c}\boldsymbol{K}_{\mathbf{m}} \\
(\boldsymbol{\mu M})\end{array}$ & $\begin{array}{c}\boldsymbol{k}_{\text {cat }} \\
\left(\mathbf{s e c}^{-1}\right)\end{array}$ & $\begin{array}{c}\boldsymbol{k}_{\text {cat }} / \boldsymbol{K}_{\mathbf{m}} \\
\left(\mathbf{M}^{-1} \mathbf{s}^{-1}\right)\end{array}$ \\
\hline CLMP-N & $(20.65-21.48)^{\mathrm{a}}$ & $(0.55-0.57)^{\mathrm{a}}$ & $\left(2.6 \times 10^{4}-2.7 \times 10^{4}\right)^{\mathrm{a}}$ \\
\hline CLMP & $(22.61-24.75)^{\mathrm{b}}$ & $(0.57-0.60)^{\mathrm{b}}$ & $\left(2.4 \times 10^{4}-2.5 \times 10^{4}\right)^{\mathrm{b}}$ \\
\hline Native & $(13.38-14.29)^{\mathrm{c}}$ & $(0.40-0.43)^{\mathrm{c}}$ & $\left(2.9 \times 10^{4}-3.0 \times 10^{4}\right)^{\mathrm{c}}$ \\
\hline
\end{tabular}


Taking into account the $K_{\mathrm{m}}$ and $\mathrm{k}_{\mathrm{cat}}$ values, the catalytic efficiency, $\left(k_{\mathrm{cat}} / K_{\mathrm{m}}\right)$, decreases upon immobilization and the addition of nanoparticles, compared to the native lipase, due to the observed increase in $K_{\mathrm{m}}$ values. These data show similar catalytic behaviors between CLMP-N and CLMP, suggesting the macrostructure of the microparticle may have a more significant impact on the apparent kinetic parameters than the presence of nanoparticles. Furthermore, these apparent kinetic parameters display overall advantageous properties of immobilized lipase at a hydrophobic interface.

\subsection{3. pH Stability}

After 24 hours at $30^{\circ} \mathrm{C}, \mathrm{CLMP}-\mathrm{N}$ retained $43 \%, 66 \%$, and $76 \%$ activity at $\mathrm{pH} 3,7$, and 10 , respectively. CLMP retained $35 \%, 61 \%$, and $70 \%$ activity at $\mathrm{pH} 3,7$, and 10 , respectively (Figure 5).

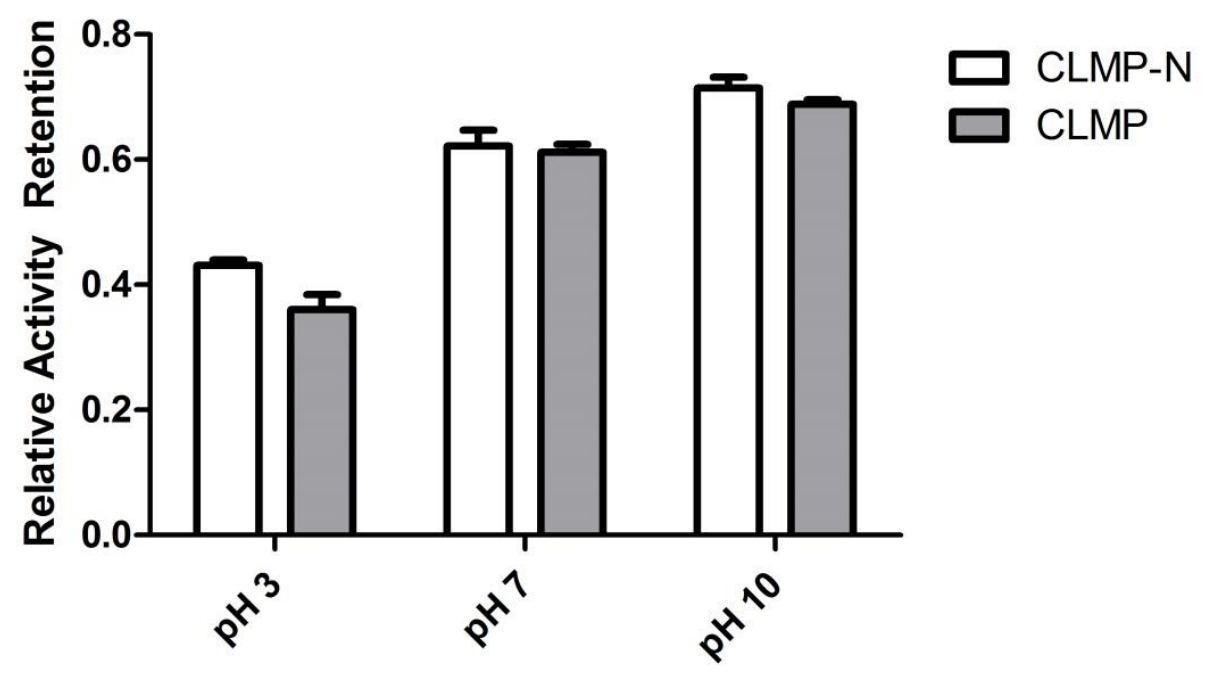

Figure 5. Relative activity retention of CLMP-N and CLMP after 24 hours exposure to $\mathrm{pH} \mathrm{3,} 7$ and 10 buffers at $30^{\circ} \mathrm{C}$. Activity remaining after 24 hours was tested using resorufin butyrate $\left(50{ }^{\circ} \mathrm{C}\right.$ in $10 \mathrm{mM}$ MES buffer, $\left.\mathrm{pH} 7\right)$. Values represent average \pm standard deviation of $\mathrm{n}=4$ determinations. Data are representative of experiments performed on two independent days. 
At neutral and basic $\mathrm{pH}$ values, no significantly different stabilization of lipase was observed for both CLMP-N and CLMP. These data suggest the main mechanism of stabilization is through conformational stability given by the polydicyclopentadiene core, similar to stabilization seen with traditional immobilization methods. ${ }^{45,46}$ In addition, the core material could be influencing the microenvironment of the enzyme, providing protection from denaturation at basic $\mathrm{pH}$ values.

At $\mathrm{pH}$ 3, statistically significant stabilization of CLMP-N over CLMP was observed, supporting previous research demonstrating iron oxide nanoparticles coupled with lipase retain activity at acidic $\mathrm{pH}$ values. ${ }^{47}$ Enhanced stability of CLMP-N may be provided by the presence of nanoparticles from multipoint covalent attachment stabilization imparted from the dopamine cap on the nanoparticle surface. ${ }^{29,30}$ These data suggest the main form of stabilization throughout varying $\mathrm{pH}$ values comes from the core material. While significant differences were observed under these conditions, the proximity of the average retained activity values indicate that practical significant differences may not be observed in commercial applications. Nevertheless, these results demonstrate the potential of hierarchical systems to be tailored to specific applications for maximum stability.

\subsubsection{Stability in Deep Eutectic Solvent (DES)}

Both CLMP-N and CLMP were exposed to the deep eutectic solvent $\mathrm{ChCl:U}$ for 48 hours. $\mathrm{ChCl}$ : $\mathrm{U}$ was chosen as the solvent for the production of glucose esters because of the lack of excess hydroxyl groups. These hydroxyl groups, present in the deep eutectic solvent formed from choline chloride and glycerol, can interfere with the 
esterification reaction, leading to the formation of secondary products. ${ }^{37}$ Elevated temperatures at $50{ }^{\circ} \mathrm{C}$ and $60{ }^{\circ} \mathrm{C}$ were used to decrease the viscosity of $\mathrm{ChCl}: \mathrm{U}$ to promote adequate mixing of the reactants and microparticles. Native lipase was not included as a control, as previous research showed complete inactivation of native lipase in less than two hours in buffer at $50{ }^{\circ} \mathrm{C}$ and $60{ }^{\circ} \mathrm{C} .{ }^{33}$ Likewise, the commercially available catalyst, Novozym 435 was unable to be included because of the inability to accurately separate and recover the catalyst from $\mathrm{ChCl}: \mathrm{U}$ for activity measurements with resorufin butyrate. Previous stability testing of Novozym 435 required dry dilution in sand to match protein concentration to the microparticles for accurate activity testing, further complicating catalyst recovery. ${ }^{33}$ As expected, both samples retained higher activity at $50{ }^{\circ} \mathrm{C}$ than $60{ }^{\circ} \mathrm{C}$ (Figure 4). After 48 hours, CLMP-N retained $71 \%$ activity at $50{ }^{\circ} \mathrm{C}$, and $33 \%$ activity at $60{ }^{\circ} \mathrm{C}$, while CLMP retained $61 \%$ activity at $50{ }^{\circ} \mathrm{C}$, and $23 \%$ activity at $60^{\circ} \mathrm{C}$.

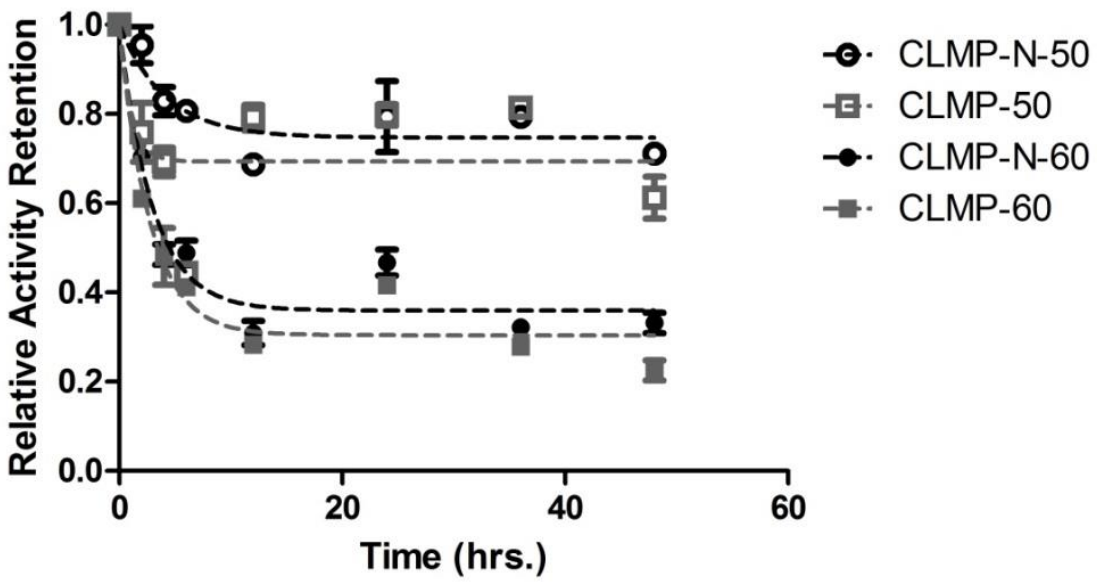

Figure 6. Relative activity retention of CLMP-N and CLMP after exposure to ChCl:U at $50^{\circ} \mathrm{C}$ and $60^{\circ} \mathrm{C}$. Residual activity was testing using resorufin butyrate as the substrate at $50^{\circ} \mathrm{C}$ in $10 \mathrm{mM}$ MES buffer, $\mathrm{pH} 7$. Values represent average \pm standard deviation of $\mathrm{n}=4$ determinations. Data are representative of experiments performed on two independent days. 
CLMP-N and CLMP displayed similar inactivation profiles: an initial drop in activity, followed by stabilization of the enzyme suggesting the stability lipase is being controlled by the core material. This finding supports previous research demonstrating immobilized lipases retain activity due to structural restrictions, which prevent

aggregation. ${ }^{45,46}$ As expected, a sharper decrease in activity is observed at $60{ }^{\circ} \mathrm{C}$ than 50 ${ }^{\circ} \mathrm{C}$ because of the more extreme environment. Retained activity was calculated based on the initial activity of the microparticles before exposure to $\mathrm{ChCl}: \mathrm{U}$ and elevated temperature.

Approximately $70 \%$ activity retention after 24 hours by CLMP-N is in accordance with previously published data of the thermostability of CLMP-N in buffer. ${ }^{33}$ However, CLMP-N activity observed in $\mathrm{ChCl:U}$ at $60{ }^{\circ} \mathrm{C}$ is lower than that reported in buffer, suggesting increased interactions of $\mathrm{ChCl}: \mathrm{U}$, furthermore decreasing stability of the enzyme. However, the sustained activity exhibited by CLMP and CLMP-N over extended time further demonstrate feasibility of the use of $\mathrm{ChCl}: \mathrm{U}$ for the production of glucose esters.

\subsubsection{Influence of DES Exposure on Apparent Kinetic Parameters}

The kinetic parameters of CLMP-N and CLMP after 12 hours exposure to $\mathrm{ChCl:U}$ at 50 and $60{ }^{\circ} \mathrm{C}$ were analyzed to determine the mechanism of lipase destabilization (Tables 2 and 3). 
Table 2. Apparent kinetic parameters of CLMP-N and CLMP following exposure to 12 hours in $\mathrm{ChCl}: \mathrm{U}$ at $50{ }^{\circ} \mathrm{C}$. Values represent $95 \%$ confidence intervals of $\mathrm{n}=4$ determinations with superscripts indicating significant differences at $p<0.05$. Data are representative of experiments performed on two independent days.

\begin{tabular}{|c|c|c|c|}
\hline $\mathbf{5 0}{ }^{\circ} \mathbf{C}$ & $\begin{array}{c}\boldsymbol{K}_{\mathbf{m}} \\
(\boldsymbol{\mu M})\end{array}$ & $\begin{array}{c}\boldsymbol{k}_{\text {cat }} \\
\left(\mathbf{s e c}^{-1}\right)\end{array}$ & $\begin{array}{c}\boldsymbol{k}_{\text {cat }} / \boldsymbol{K}_{\mathbf{m}} \\
\left(\mathbf{M}^{-1} \mathbf{s}^{-1}\right)\end{array}$ \\
\hline CLMP-N & $(23.71-34.76)^{\mathrm{a}}$ & $(0.26-0.36)^{\mathrm{a}}$ & $\left(0.87 \times 10^{4}-1.3 \times 10^{4}\right)^{\mathrm{a}}$ \\
\hline CLMP-N Initial & $(22.82-27.98)^{\mathrm{ab}}$ & $(0.40-0.42)^{\mathrm{b}}$ & $\left(1.5 \times 10^{4}-1.8 \times 10^{4}\right)^{\mathrm{b}}$ \\
\hline CLMP & $(24.96-33.44)^{\mathrm{a}}$ & $(0.33-0.36)^{\mathrm{c}}$ & $\left(1.1 \times 10^{4}-1.3 \times 10^{4}\right)^{\mathrm{a}}$ \\
\hline CLMP Initial & $(23.17-24.08)^{\mathrm{b}}$ & $(0.45-0.46)^{\mathrm{d}}$ & $\left(1.9 \times 10^{4}-2.0 \times 10^{4}\right)^{\mathrm{c}}$ \\
\hline
\end{tabular}

Table 3. Apparent kinetic parameters of CLMP-N and CLMP following exposure to 12 hours in ChCl:U at $60{ }^{\circ} \mathrm{C}$. Values represent 95\% confidence intervals of $\mathrm{n}=4$ determinations with superscripts indicating significant differences at $\mathrm{p}<0.05$. Data are representative of experiments performed on two independent days.

\begin{tabular}{|c|c|c|c|}
\hline $\mathbf{6 0}^{\circ} \mathbf{C}$ & $\begin{array}{c}\boldsymbol{K}_{\mathbf{m}} \\
(\boldsymbol{\mu M})\end{array}$ & $\begin{array}{c}\boldsymbol{k}_{\text {cat }} \\
\left(\mathbf{s e c}^{-1}\right)\end{array}$ & $\begin{array}{c}\boldsymbol{k}_{\text {cat }} / \boldsymbol{K}_{\mathbf{m}} \\
\left(\mathbf{M}^{-1} \mathbf{s}^{-1}\right)\end{array}$ \\
\hline CLMP-N & $(33.89-36.79)^{\mathrm{a}}$ & $(0.16-0.18)^{\mathrm{a}}$ & $\left(0.42 \times 10^{4}-0.52 \times 10^{4}\right)^{\mathrm{a}}$ \\
\hline CLMP-N Initial & $(30.87-36.43)^{\mathrm{a}}$ & $(0.35-0.38)^{\mathrm{b}}$ & $\left(1.0 \times 10^{4}-1.1 \times 10^{4}\right)^{\mathrm{b}}$ \\
\hline CLMP & $(34.80-37.12)^{\mathrm{a}}$ & $(0.16-0.19)^{\mathrm{a}}$ & $\left(0.45 \times 10^{4}-0.55 \times 10^{4}\right)^{\mathrm{a}}$ \\
\hline CLMP Initial & $(33.75-36.97)^{\mathrm{a}}$ & $(0.39-0.42)^{\mathrm{c}}$ & $\left(1.1 \times 10^{4}-1.2 \times 10^{4}\right)^{\mathrm{c}}$ \\
\hline
\end{tabular}

At $50{ }^{\circ} \mathrm{C}$ and $60{ }^{\circ} \mathrm{C}$, both CLMP-N and CLMP showed increased $K_{\mathrm{m}}$ values compared to the control, which had not been exposed to elevated temperatures or deep eutectic solvents. The increased $K_{\mathrm{m}}$ values of CLMP-N and CLMP were not significantly different from each other or the controls, suggesting limited restriction of the active site. Since the particles are recovered from the viscous $\mathrm{ChCl}: \mathrm{U}$ with water, there is a potential for residual $\mathrm{ChCl}: \mathrm{U}$ to be held on the surface from hydrogen bonding, resulting in higher deviations compared to the controls. The residual solvent coating the surface of the particle could restrict substrate interaction with the active site, explaining the increase in 
$K_{\mathrm{m}}$ seen at $50{ }^{\circ} \mathrm{C}$ for CLMP. However, this increase was not significantly different for CLMP-N at $50{ }^{\circ} \mathrm{C}$ and both CLMP and CLMP-N at $60{ }^{\circ} \mathrm{C}$, suggesting limited impact of residual solvent.

Following exposure to both $50{ }^{\circ} \mathrm{C}$ and $60{ }^{\circ} \mathrm{C}$ in $\mathrm{ChCl}: \mathrm{U}$, both CLMP-N and CLMP displayed a significant decrease in the apparent turnover number, $k_{\text {cat }}$. Furthermore, both samples showed a significant decrease in catalytic efficiency $\left(k_{\mathrm{cat}} / K_{\mathrm{m}}\right)$. The observed decrease in $k_{\text {cat }}$ suggests conformational changes to the structure of lipase, which impact the rate of catalysis. The insignificant changes in $K_{\mathrm{m}}$ observed for CLMP$\mathrm{N}$ at $50{ }^{\circ} \mathrm{C}$, and CLMP-N and CLMP at $60{ }^{\circ} \mathrm{C}$ suggest active site binding is not impacted by these conformational changes. As expected, higher decreases in kinetic parameters were observed at $60^{\circ} \mathrm{C}$ than $50{ }^{\circ} \mathrm{C}$.

At each temperature, no practical differences between CLMP-N and CLMP were displayed, suggesting enzyme stabilization in $\mathrm{ChCl}: \mathrm{U}$ is imparted from the macrostructure. These data show the entrapment of the enzyme structure in the polydicyclopentadiene impacts enzyme stability greater than nanoparticles, agreeing with previous research showing entrapment of lipase in a hydrophobic material improves thermostability. ${ }^{45}$

\subsubsection{Glucose Ester Synthesis in DES}

CLMP, CLMP-N and Novozym 435 (N435) were exposed to direct esterification reaction conditions for 12 hours at $50{ }^{\circ} \mathrm{C}$. Temperature selection was based on stability testing, where CLMP and CLMP-N retain over $60 \%$ activity at $50{ }^{\circ} \mathrm{C}$ in $\mathrm{ChCl}: \mathrm{U}$ throughout 12 hours of exposure. Novozym 435 was selected as a commercially available form of immobilized lipase. Initial glucose, lauric acid, and Novozym 435 
concentrations were selected based on prior reports of lipase-catalyzed direct esterification within ionic liquids. ${ }^{41,48,49}$ From empirical calculations, the amount of protein present in Novozym 435 was estimated to be $2500 \mu \mathrm{g}$ protein/50 $\mathrm{mg}$ solid support, while CLMP and CLMP-N estimated to be $50 \mu \mathrm{g}$ protein per reaction vial. To account for the large difference in protein content, reported values were normalized to represent percent of glucose converted per $\mu \mathrm{g}$ protein. After 12 hours, Novozym 435 converted $0.002 \pm 0.001 \%$ glucose per $\mu \mathrm{g}$ protein (Figure $7 \mathrm{a}$ ), and CLMP and CLMP-N converted $0.23 \pm 0.06 \%$, and $0.14 \pm 0.07 \%$ glucose per $\mu$ g protein, respectively. Previous research has shown correlation between the DNS method for reducing sugar quantification and HPLC quantification. $^{48}$

a)

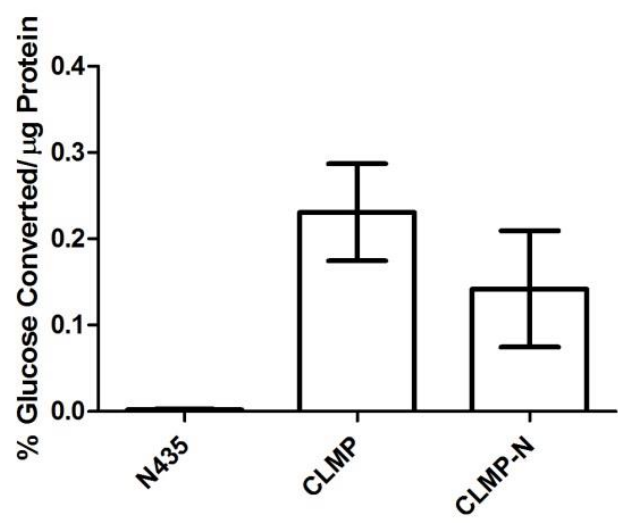

b)

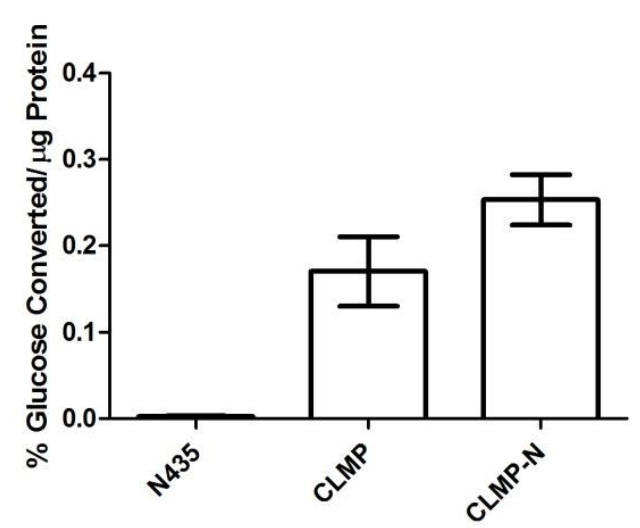

Figure 7. Percent conversion of glucose per $\mu \mathrm{g}$ protein in $\mathrm{ChCl}: \mathrm{U}$ at $50{ }^{\circ} \mathrm{C}$ after 12 hours exposure to Novozym 435, CLMP, and CLMP-N for a) direct esterification and b) transesterification. Values represent average \pm standard deviation of $n=8$ determinations. Data are representative of experiments performed on two independent days.

Per unit protein, CLMP is approximately 114 times more active than the industry standard, and CLMP-N is approximately 70 times more active. After exposure to $\mathrm{ChCl}: \mathrm{U}, \mathrm{CLMP}$ retained a higher turnover rate $\left(k_{\mathrm{cat}}\right)$ than CLMP-N, possibly explaining 
the higher activity exhibited by CLMP over CLMP-N when applied to direct esterification. Previous reports of kinetic analysis using a synthetic substrate demonstrated that CLMP-N is more efficient than Novozym 435, further supporting the findings. ${ }^{33}$ The increased surface area of CLMP/CLMP-N compared to Novozym 435 may reduce mass-transfer limitations and steric hindrance, thus increasing conversion to product. Since Novozym 435 could not be tested for stability in ChCl:U because of handling considerations with the synthetic substrate, Novozym 435 may experience steric hindrance from the high amount of protein loaded onto the support. The viscosity of $\mathrm{ChCl:U}$ increases upon the addition of reactants, which may impart mass transfer limitations, inhibit the reaction, and increase deviation. Direct esterification is governed by the buildup of the secondary product, water. ${ }^{50}$ Thus, molecular sieves were added to absorb water prior to and throughout the reaction, however small amounts of water may still inhibit the process. As a result, transesterification was studied to circumvent the issue of aqueous inhibition.

Transesterification is considered a more favorable pathway for lipase because the secondary product, ethenol, is rapidly tautomerized to acetaldehyde, driving the reaction towards completion. Following 12 hours exposure at $50{ }^{\circ} \mathrm{C}$, Novozym 435 converted $0.002 \pm 0.001 \%$ glucose per $\mu$ g protein, while CLMP and CLMP-N converted $0.17 \pm 0.04 \%$ and $0.25 \pm 0.03 \%$ glucose per $\mu \mathrm{g}$ protein, respectively (Figure $7 \mathrm{~b}$ ). As observed with direct esterification, CLMP and CLMP-N perform significantly better than Novozym 435, per unit protein. Novozym 435 activity was similar for direct esterification, suggesting inactivation of the enzyme, or mass transfer limitations, due to the viscosity of the deep eutectic solvent. CLMP-N showed an increase in activity 
compared to direct esterification, which was expected due to the reaction mechanism. However, CLMP activity for transesterification was not significantly different from the activity seen during direct esterification. The difference in activity during transesterification between CLMP and CLMP-N may imply that the presence of nanoparticles does influence substrate affinity for certain substrates. Apparent kinetic parameters determined with a synthetic substrate, are specific to that given substrate, and can change with the substrate; hence differences were observed between direct esterification and transesterification. Because of the inherent error associated with the viscous deep eutectic solvent, differences in percent conversion may also be due to insufficient mixing or aggregation of the microparticles. Nonetheless, CLMP and CLMP-N demonstrate significant advantages over Novozym 435 for both direct esterification and transesterification, per unit protein.

\subsection{Conclusions}

Hierarchical structures, incorporating both macrostructures and nanostructures, can provide enhanced stability to immobilized enzyme systems through stabilizing the structure and microenvironment of the enzyme. Apparent kinetic parameters reveal similarities between CLMP-N and CLMP, the macrostructure dictates kinetic parameters for this hierarchical system. Stability testing in varying $\mathrm{pH}$ values demonstrated that nanoparticles may influence the microenvironment of the enzyme, providing additional stability for this system. Stabilization of lipase in deep eutectic solvents, elevated temperatures and alkaline conditions is likely due to protein structure and microenvironment stabilization from the macrostructure, polydicyclopentadiene. Lipase 
microparticles exhibited stabilized activity for 48 hours of time in $\mathrm{ChCl:U}$, and performed better than the commercially available immobilized lipase when applied to the synthesis of glucose esters. For direct esterification, the macrostructure dictated lipase activity in $\mathrm{ChCl:U}$; however, for transesterification, the presence of nanoparticles may influence activity towards vinyl esters. Further optimization of reaction conditions has the potential to increase total product yield and activity. A greater understanding of hierarchical systems can lead to tailor-made biocatalyst systems with enhanced stability and practical application in the food and bioprocessing industries. 


\section{CHAPTER 2}

\section{RECOMMENDATIONS FOR FUTURE RESEARCH}

Hierarchical systems show potential for enhanced enzyme activity and stability in extreme environments. The aforementioned research showed the application of hierarchical systems for the production of value-added agricultural products in deep eutectic solvents. However, the feasibility of commercial application of the deep eutectic solvent, ChCl: $\mathrm{U}$, is low due to the high viscosity of the solvent. Additionally, for the production of sugar esters using glucose and lauric acid/vinyl laurate, a different solvent should be explored, as the product is difficult to extract from the reaction mixture. To continue optimization of the production of sugar esters in $\mathrm{ChCl}: \mathrm{U}$, I recommend the following:

- Increase the temperature of the reaction to $60^{\circ} \mathrm{C}$ to further reduce viscosity.

- Explore other sugars (e.g. fructose, maltose) and both lower and higher chain lengths of fatty acids- to find a product less soluble in $\mathrm{ChCl:U}$.

- Use a method other than rotation for mixing- possibly magnetic stirring in a reaction block.

It is recommended to explore other solvents than $\mathrm{ChCl}: \mathrm{U}$ for the production of sugar esters, especially those with lower viscosities. Additionally, because of the inherent difficulties in the recovery of a surfactant product, other reactions should be explored using hierarchical systems. This type of system has the ability to be used for various applications such as biodiesel production and in biosensors. This research presents methods for understanding how hierarchical systems can be tailored for specific processing applications. 


\section{LITERATURE CITED}

(1) Montgomery, R. Development of biobased products. Bioresour. Technol. 2004, 91 (1), 1-29.

(2) Neta, N. S.; Teixeira, J. A.; Rodrigues, L. R. Sugar Ester Surfactants: Enzymatic Synthesis and Applications in Food Industry. Crit. Rev. Food Sci. Nutr. 2015, 55 (5), 595-610.

(3) Jaeger, K. E.; Reetz, M. T. Microbial lipases form versatile tools for biotechnology. Trends Biotechnol. 1998, 16 (9), 396-403.

(4) Gumel, A. M.; Annuar, M. S. M.; Heidelberg, T.; Chisti, Y. Lipase mediated synthesis of sugar fatty acid esters. Process Biochem. 2011, 46 (11), 2079-2090.

(5) Degn, P.; Zimmermann, W. Optimization of carbohydrate fatty acid ester synthesis in organic media by a lipase from Candida antarctica. Biotechnol. Bioeng. 2001, 74 (6), 483-491.

(6) Degn, P.; Pedersen, L. H.; Duus, J. ø; Zimmermann, W. Lipase-catalysed synthesis of glucose fatty acid esters in tert-butanol. Biotechnol. Lett. 1999, 21 (4), 275-280.

(7) Ferrer, M.; Soliveri, J.; Plou, F. J.; López-Cortés, N.; Reyes-Duarte, D.; Christensen, M.; Copa-Patiño, J. L.; Ballesteros, A. Synthesis of sugar esters in solvent mixtures by lipases from Thermomyces lanuginosus and Candida antarctica B, and their antimicrobial properties. Enzyme Microb. Technol. 2005, 36 (4), 391-398.

(8) Yu, J.; Zhang, J.; Zhao, A.; Ma, X. Study of glucose ester synthesis by immobilized lipase from Candida sp. Catal. Commun. 2008, 9 (6), 1369-1374.

(9) Jin, Z.; Liang, S.; Zhang, X.; Han, S.; Ren, C.; Lin, Y.; Zheng, S. Synthesis of fructose laurate esters catalyzed by a CALB-displaying Pichia pastoris whole-cell biocatalyst in a non-aqueous system. Biotechnol. Bioprocess Eng. 2013, 18 (2), 365-374.

(10) Li, L.; Ji, F.; Wang, J.; Li, Y.; Bao, Y. Esterification degree of fructose laurate exerted by Candida antarctica lipase B in organic solvents. Enzyme Microb. Technol. 2015, 69, 46-53.

(11) Arcos, J. A.; Bernabé, M.; Otero, C. Quantitative enzymatic production of 6-O acylglucose esters. Biotechnol. Bioeng. 1998, 57 (5), 505-509.

(12) Domínguez de María, P.; Maugeri, Z. Ionic liquids in biotransformations: from proof-of-concept to emerging deep-eutectic-solvents. Curr. Opin. Chem. Biol. 2011, 15 (2), 220-225. 
(13) Zhang, Q.; De Oliveira Vigier, K.; Royer, S.; Jérôme, F. Deep eutectic solvents: syntheses, properties and applications. Chem. Soc. Rev. 2012, 41 (21), 7108.

(14) Abbott, A. P.; Capper, G.; Davies, D. L.; Rasheed, R. K.; Tambyrajah, V. Novel solvent properties of choline chloride/urea mixtures. Chem. Commun. 2003, No. 1, $70-71$.

(15) Pöhnlein, M.; Ulrich, J.; Kirschhöfer, F.; Nusser, M.; Muhle-Goll, C.; Kannengiesser, B.; Brenner-Weiß, G.; Luy, B.; Liese, A.; Syldatk, C.; et al. Lipase-catalyzed synthesis of glucose-6-O-hexanoate in deep eutectic solvents. Eur. J. Lipid Sci. Technol. 2015, 116.

(16) Yang, Z.; Huang, Z.-L. Enzymatic synthesis of sugar fatty acid esters in ionic liquids. Catal. Sci. Technol. 2012, 2 (9), 1767-1775.

(17) Durand, E.; Lecomte, J.; Villeneuve, P. Deep eutectic solvents: Synthesis, application, and focus on lipase-catalyzed reactions. Eur. J. Lipid Sci. Technol. 2013, 115 (4), 379-385.

(18) Durand, E.; Lecomte, J.; Baréa, B.; Piombo, G.; Dubreucq, E.; Villeneuve, P. Evaluation of deep eutectic solvents as new media for Candida antarctica B lipase catalyzed reactions. Process Biochem. 2012, 47 (12), 2081-2089.

(19) Abbott, A. P.; Boothby, D.; Capper, G.; Davies, D. L.; Rasheed, R. K. Deep Eutectic Solvents Formed between Choline Chloride and Carboxylic Acids: Versatile Alternatives to Ionic Liquids. J. Am. Chem. Soc. 2004, 126 (29), 91429147.

(20) Hwang, E. T.; Gu, M. B. Enzyme stabilization by nano/microsized hybrid materials. Eng. Life Sci. 2013, 13 (1), 49-61.

(21) Sheldon, R. A.; Pelt, S. van. Enzyme immobilisation in biocatalysis: why, what and how. Chem. Soc. Rev. 2013, 42 (15), 6223-6235.

(22) Kim, J.; Grate, J. W.; Wang, P. Nanostructures for enzyme stabilization. Chem. Eng. Sci. 2006, 61 (3), 1017-1026.

(23) Ansari, S. A.; Husain, Q. Potential applications of enzymes immobilized on/in nano materials: A review. Biotechnol. Adv. 2012, 30 (3), 512-523.

(24) Cipolatti, E. P.; Silva, M. J. A.; Klein, M.; Feddern, V.; Feltes, M. M. C.; Oliveira, J. V.; Ninow, J. L.; de Oliveira, D. Current status and trends in enzymatic nanoimmobilization. J. Mol. Catal. B Enzym. 2014, 99, 56-67.

(25) Vertegel, A. A.; Siegel, R. W.; Dordick, J. S. Silica Nanoparticle Size Influences the Structure and Enzymatic Activity of Adsorbed Lysozyme. Langmuir 2004, 20 (16), 6800-6807. 
(26) Asuri, P.; Karajanagi, S. S.; Yang, H.; Yim, T.-J.; Kane, R. S.; Dordick, J. S. Increasing Protein Stability through Control of the Nanoscale Environment. Langmuir 2006, 22 (13), 5833-5836.

(27) Shang, W.; Nuffer, J. H.; Muñiz-Papandrea, V. A.; Colón, W.; Siegel, R. W.; Dordick, J. S. Cytochrome c on Silica Nanoparticles: Influence of Nanoparticle Size on Protein Structure, Stability, and Activity. Small 2009, 5 (4), 470-476.

(28) Talbert, J. N.; Goddard, J. M. Characterization of lactase-conjugated magnetic nanoparticles. Process Biochem. 2013, 48 (4), 656-662.

(29) Xu, C.; Xu, K.; Gu, H.; Zheng, R.; Liu, H.; Zhang, X.; Guo, Z.; Xu, B. Dopamine as A Robust Anchor to Immobilize Functional Molecules on the Iron Oxide Shell of Magnetic Nanoparticles. J. Am. Chem. Soc. 2004, 126 (32), 9938-9939.

(30) Qu, H.; Caruntu, D.; Liu, H.; O’Connor, C. J. Water-Dispersible Iron Oxide Magnetic Nanoparticles with Versatile Surface Functionalities. Langmuir 2011, 27 (6), 2271-2278.

(31) Laurent, S.; Forge, D.; Port, M.; Roch, A.; Robic, C.; Vander Elst, L.; Muller, R. N. Magnetic Iron Oxide Nanoparticles: Synthesis, Stabilization, Vectorization, Physicochemical Characterizations, and Biological Applications. Chem. Rev. 2008, 108 (6), 2064-2110.

(32) Mateo, C.; Palomo, J. M.; Fernandez-Lorente, G.; Guisan, J. M.; FernandezLafuente, R. Improvement of enzyme activity, stability and selectivity via immobilization techniques. Enzyme Microb. Technol. 2007, 40 (6), 1451-1463.

(33) Talbert, J. N.; Wang, L.-S.; Duncan, B.; Jeong, Y.; Andler, S. M.; Rotello, V. M.; Goddard, J. M. Immobilization and Stabilization of Lipase (CaLB) through Hierarchical Interfacial Assembly. Biomacromolecules 2014, 15 (11), 3915-3922.

(34) Andler, S. M.; Wang, L.-S.; Goddard, J. M.; Rotello, V. M. Preparation of Biocatalytic Microparticles by Interfacial Self-Assembly of Enzyme-Nanoparticle Conjugates Around a Cross-Linkable Core. Methods Enzymol. 2016, In Press. DOI: http://dx.doi.org/10.1016/bs.mie.2016.02.005.

(35) Samanta, B.; Yang, X.-C.; Ofir, Y.; Park, M.-H.; Patra, D.; Agasti, S. S.; Miranda, O. R.; Mo, Z.-H.; Rotello, V. M. Catalytic Microcapsules Assembled from Enzyme-Nanoparticle Conjugates at Oil-Water Interfaces. Angew. Chem. Int. Ed. 2009, 48 (29), 5341-5344.

(36) Jeong, Y.; Duncan, B.; Park, M.-H.; Kim, C.; Rotello, V. M. Reusable biocatalytic crosslinked microparticles self-assembled from enzyme-nanoparticle complexes. Chem. Commun. 2011, 47 (44), 12077-12079. 
(37) Kleiner, B.; Schörken, U. Native lipase dissolved in hydrophilic green solvents: A versatile 2-phase reaction system for high yield ester synthesis. Eur. J. Lipid Sci. Technol. 2015, 117 (2), 167-177.

(38) Sapan, C. V.; Lundblad, R. L.; Price, N. C. Colorimetric protein assay techniques. Biotechnol. Appl. Biochem. 1999, 29, 99-108.

(39) Henley, J. P.; Sadana, A. Series-type Enzyme Deactivation Kinetics: Influence of Immobilization, Chemical Modifiers, and Enzyme Aging. Ann. N. Y. Acad. Sci. 1984, 434 (1), 064-069.

(40) Reis, P.; Holmberg, K.; Watzke, H.; Leser, M. E.; Miller, R. Lipases at interfaces: A review. Adv. Colloid Interface Sci. 2009, 147-48, 237-250.

(41) Lee, S. H.; Dang, D. T.; Ha, S. H.; Chang, W.-J.; Koo, Y.-M. Lipase-catalyzed synthesis of fatty acid sugar ester using extremely supersaturated sugar solution in ionic liquids. Biotechnol. Bioeng. 2008, 99 (1), 1-8.

(42) Miller, G. L. Use of Dinitrosalicylic Acid Reagent for Determination of Reducing Sugar. Anal. Chem. 1959, 31 (3), 426-428.

(43) Talbert, J. N.; Goddard, J. M. Influence of nanoparticle diameter on conjugated enzyme activity. Food Bioprod. Process. 2013, 91 (4), 693-699.

(44) Bastida, A.; Sabuquillo, P.; Armisen, P.; Fernández-Lafuente, R.; Huguet, J.; Guisán, J. M. A single step purification, immobilization, and hyperactivation of lipases via interfacial adsorption on strongly hydrophobic supports. Biotechnol. Bioeng. 1998, 58 (5), 486-493.

(45) Liu, J.; Bai, S.; Jin, Q.; Li, C.; Yang, Q. Enhanced thermostability of enzymes accommodated in thermo-responsive nanopores. Chem. Sci. 2012, 3 (12), 33983402.

(46) Zhang, N. Y.; Suen, W. C.; Windsor, W.; Xiao, L.; Madison, V.; Zaks, A. Improving tolerance of Candida antarctica lipase B towards irreversible thermal inactivation through directed evolution. Protein Eng. 2003, 16 (8), 599-605.

(47) Ren, Y.; Rivera, J. G.; Lihong He; Kulkarni, H.; Dong-Keun Lee; Messersmith, P. B. Facile, high efficiency immobilization of lipase enzyme on magnetic iron oxide nanoparticles via a biomimetic coating. BMC Biotechnol. 2011, 11 (1), 63-70.

(48) Lee, S. H.; Nguyen, H. M.; Koo, Y.-M.; Ha, S. H. Ultrasound-enhanced lipase activity in the synthesis of sugar ester using ionic liquids. Process Biochem. 2008, 43 (9), 1009-1012. 
(49) Lee, S. H.; Ha, S. H.; Hiep, N. M.; Chang, W.-J.; Koo, Y.-M. Lipase-catalyzed synthesis of glucose fatty acid ester using ionic liquids mixtures. J. Biotechnol. 2008, 133 (4), 486-489.

(50) Flores, M. V.; Naraghi, K.; Engasser, J.-M.; Halling, P. J. Influence of glucose solubility and dissolution rate on the kinetics of lipase catalyzed synthesis of glucose laurate in 2-methyl 2-butanol. Biotechnol. Bioeng. 2002, 78 (7), 815-821. 